Proc. Estonian Acad. Sci. Eng., 2006, 12, 4, 408-418

\title{
Impact wear in mineral crushing
}

\author{
Tuomas Teeri $^{\mathrm{a}}$, Veli-Tapani Kuokkala ${ }^{\mathrm{a}}$, Pekka Siitonen ${ }^{\mathrm{b}}$, \\ Päivi Kivikytö-Reponen ${ }^{\mathrm{b}}$ and Jari Liimatainen ${ }^{\mathrm{b}}$ \\ a Institute of Materials Science, Tampere University of Technology, POB 589, 33101 Tampere, \\ Finland; tuomas.teeri@tut.fi \\ b Metso Powdermet Oy, POB 237, 33101 Tampere, Finland \\ Received 2 June 2006, in revised form 2 October 2006
}

\begin{abstract}
Mining and mineral processing demand wear-resistant machines and components, because the energies and masses of interacting bodies are significant. This paper is concerned with the wear mechanisms, which occur in grinding mills. Conditions of severe-impact wear and impactabrasion, and wear behaviour of the lifter bars are studied. A hammer-mill type device, which can produce high-energy impacts, was used. The experiments were also carried out in conditions with abrasive particles present. The wear behaviour of several PM materials and a few reference materials were compared in certain wear conditions. Different material properties that influence the wear resistance were also studied. The microstructure and homogeneity of the materials were studied mainly with a scanning electron microscope. On the basis of the experimental results the studied materials were classified.
\end{abstract}

Key words: impact wear, impact-abrasion, mineral processing, grinding mill, PM materials.

\section{INTRODUCTION}

Tribology is a science, which is concentrated on interacting surfaces in relative motion. Interactions like friction, wear and lubrication take place and are the main factors of a complete tribosystem. Wear is a phenomenon caused by moving surfaces and their interaction, which cause material loss from the surface. There are numerous influencing factors in a tribological system and handling all or even most of them is very challenging. Theoretical laws of tribology and wear are continuously challenged by scientific research $\left[{ }^{1}\right]$.

This study focuses on specific wear types, which are related to mineral processing. Impact wear, abrasion and their combinations are the most important cost factors in the areas of mining and mineral processing. The main goal of this 
study is to find the optimal powder-metallurgical materials for mineral processing, especially for grinding mills and their lining systems. Liner wear has a great influence on the mill performance and maximization of the liner life is important to the operators and manufacturers $\left[{ }^{2}\right]$. The chosen material should have good resistance against impact-abrasive wear and adequate other mechanical properties. Another goal is to optimize the heat treatment of the chosen material and to develop further its wear resistance.

Grinding is the last stage in the communition process. The ore particles are reduced in size by a combination of impact and abrasion $\left[{ }^{3}\right]$. The grinding process is the largest energy consumer in the mineral industry. Grinding in ball mills accounts for up to 40 percent of the operating cost of a processing plant $\left[{ }^{4}\right]$.

A single tribosystem in a grinding mill is shown in Fig. 1. Environment inside a grinding mill consists basically of air, water and dust. Grinding media is considered here as the counterbody, which creates impact wear on the solid body. Interfacial element is a large amount of ore particles, which act as an abrasive component in this tribosystem. The liners of a grinding mill are the elements that are affected by the wear $\left.{ }^{5,6}\right]$.

To gain more information in this field, one should perform tribosimulative tests, which mimic the real process as well as possible. Tribosimulation is a test, whose purpose is to imitate the conditions and environment of a particular machine component. When designing a tribosimulation, the main question is to find the most significant wear mechanisms and to design a test device, which produces the same kind of wear response $\left[^{7}\right]$.

Engineers often criticize tribosimulation, because the results of laboratory tests have turned out useless in many practical applications. This criticism is often due to overestimation and misinterpretation of published wear rates and friction coefficients. Tribological systems and wear mechanisms and their details are easily underestimated when engineers concentrate on material properties, ignoring the properties of the whole system $\left[{ }^{8}\right]$.

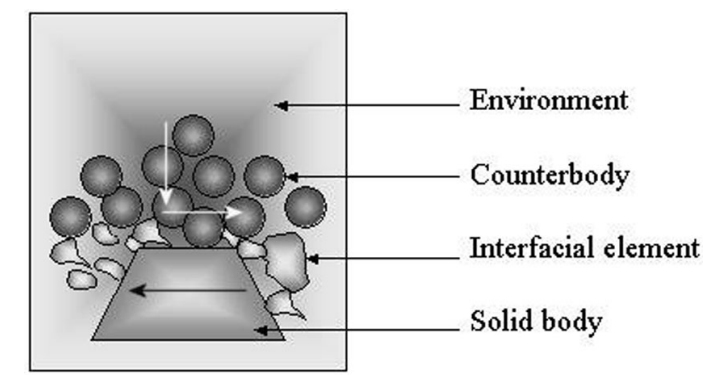

Fig. 1. Tribosystem of a single lifter bar $\left[{ }^{5}\right]$. 


\section{EXPERIMENTAL PART}

\subsection{Test device}

The hammer-mill device, used in this study, was modified from an existing device, which was built earlier for a similar project [ $\left.{ }^{9}\right]$ (Fig. 2). The main objective of this hammer-mill type machine was to demonstrate severe impact conditions and impact conditions combined with abrasive particles. Such conditions take place in rotating grinding mills in ore processing.

The hammer-mill was found to be suitable for the control of the impact energy because of its well-adjustable controls. The factors that the user is able to modify are the impact angle, impact energy, material of the hammers, movement of the specimen table and the feeding rate of abrasive particles.

\subsection{Tested materials}

Modern Tribology Handbook $\left[{ }^{10}\right]$ suggests several different materials for grinding operation in ore processing, such as wrought martensitic steels, cast martensitic steels, alloy white irons, cast pearlite steels and elastomers and rubbers.

The materials used in this study were divided into powder-metallurgical materials and reference materials. The tested PM materials and different grades of HIP (hot isostatic pressing) tool steels were produced and delivered by Metso Powdermet. Grades WR1, WR6, WR9 and WR12 were hot worked before quenching and tempering heat treatment, whereas WR4 was tested without hot working. Two different reference materials were used: SSAB Oxelösund's Hardox 600 and a standard cast CrMo-steel. The compositions of test materials are listed in Table 1.

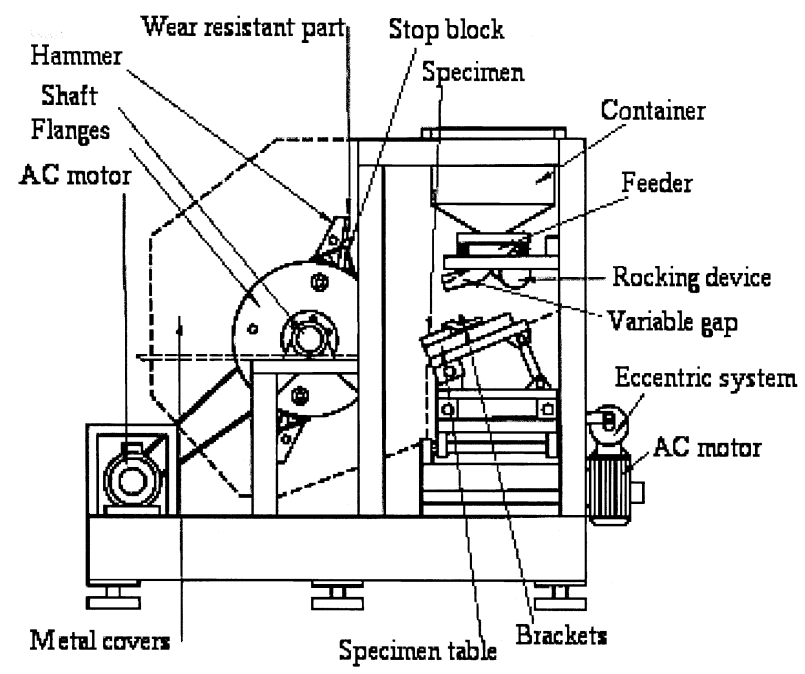

Fig. 2. The hammer-mill. 
Table 1. Compositions of the tested materials

\begin{tabular}{l|c|c|c|c|c|c|c|c|c|c}
\hline \multicolumn{1}{c}{ Material } & $\mathrm{C}$ & $\mathrm{Si}$ & $\mathrm{Mn}$ & $\mathrm{P}$ & $\mathrm{S}$ & $\mathrm{Cr}$ & $\mathrm{V}$ & $\mathrm{Mo}$ & $\mathrm{W}$ & $\mathrm{Ni}$ \\
\hline Ralloy® WR1 & 1.28 & & & & & 4.2 & 3.1 & 5.0 & 6.4 & \\
Ralloy® WR4 & 1.8 & 0.9 & $<0.5$ & & & 5.25 & 9.00 & 1.3 & & \\
Ralloy@ WR6 & 2.9 & $<1.0$ & $<1.0$ & $<0.03$ & $<0.03$ & 5.25 & 11.5 & 1.3 & & \\
Ralloy® WR9 & 0.8 & & & & & 7.5 & 2.75 & 1.3 & & \\
Ralloy® WR12 & 1.1 & & & & & 7.75 & 2.35 & 1.6 & 1.1 & \\
Hardox 600 & & 0.7 & 1 & 0.015 & 0.01 & 1.2 & & 0.8 & & 2.5 \\
CrMo & & 0.66 & & & & 2.5 & & 0.48 & &
\end{tabular}

\subsection{Test procedures}

All impact wear experiments were performed with the same impact angle and impact energy. The impact angle of hammers was chosen to be $90^{\circ}$ between the chamfer of the hammer and the specimen surface. Impact energy of a single impact was about $31 \mathrm{~J}$. The tests were designed to last $690 \mathrm{~min}$ per specimen, provided that the specimen would bear the whole test. The impact frequency was 130 impacts per minute, which lead to approximately 90000 impacts per test. Mass of the worn specimens was measured after every 3900 impacts, and the progression of wear was studied by the relation between mass loss and the number of impacts.

The specimen table was set to move within certain limits to keep the contacting specimen area constant. Movement of the specimen table was sinusoidal and it moved in a different phase compared to the hammer impacts. This enabled the impacts to be equally distributed on the specimen surface.

In the second phase of the experimental work, abrasive particles were added in the tests to simulate as well as possible a real mineral grinding process (Fig. 3). The size of the used granite abrasive particles varied from 3 to $8 \mathrm{~mm}$. The total testing time was $70 \mathrm{~min}$ with about 9100 impacts per specimen. Sand was separated from the particles with a sieve to maintain the original size fraction.

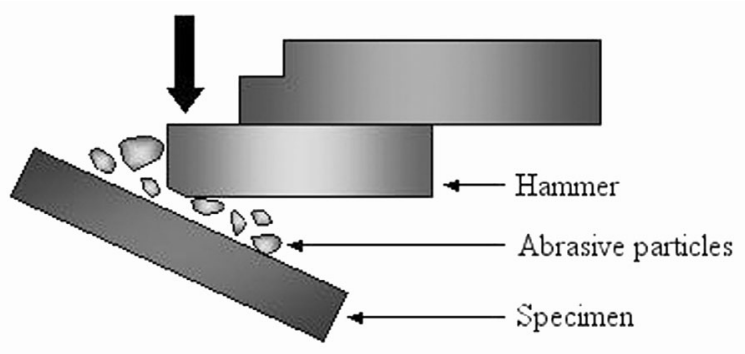

Fig. 3. The contact between the specimen and the hammer $\left[{ }^{5}\right]$. 


\section{RESULTS AND DISCUSSION}

\subsection{Results of the impact wear tests}

In the beginning of the experimental work, materials WR4 and WR6 were tested. From these first results, the following two conclusions were made: 1) HIP materials are not ductile enough without hot working, 2) the properties of WR6 were only on the level of the reference materials and should therefore be further treated. This led to the use of lower alloyed more ductile materials WR1, WR9 and WR12.

The measured total weight losses were in the order of one gram with the exception of CrMo, WR4 and Hardox 600. These materials lost from a few to several grams during the test. Among the best materials were WR9, WR12 and WR1. Their total weight losses were below $0.4 \mathrm{~g}$. All results showed quite linear behaviour without any significant fracture, with the exception of WR4.

The best materials in this test did not really obtain large deformations at all. Only very small brittle fractures occurred and sharp edges of the specimens became rounded. These small fractures took place almost always in the first period of the test, as we can see in Fig. 4. That is because in most cases the sharp front edge of the specimen deformed heavily.

In the impact-abrasion experiment WR9 and WR6 gave the best results (Fig. 5). Both versions of Ralloy WR12 did also well.

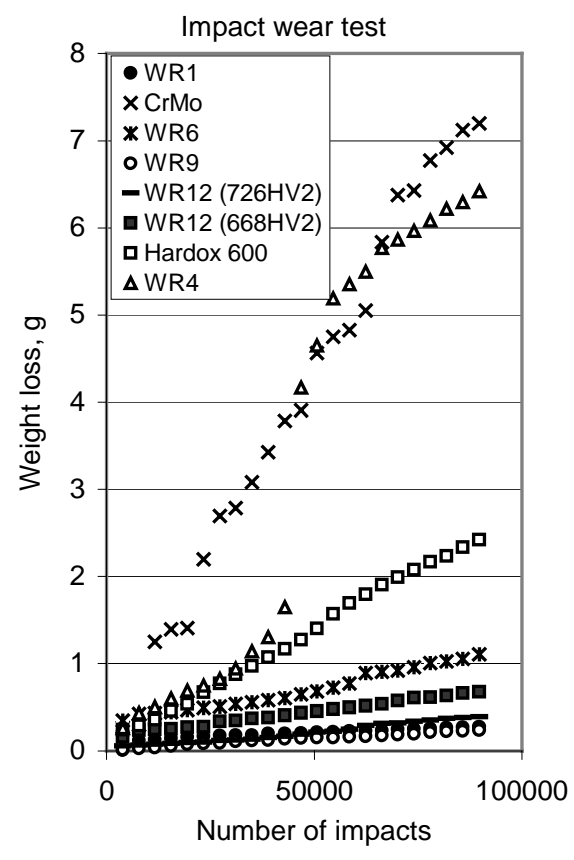

Fig. 4. Impact wear results.

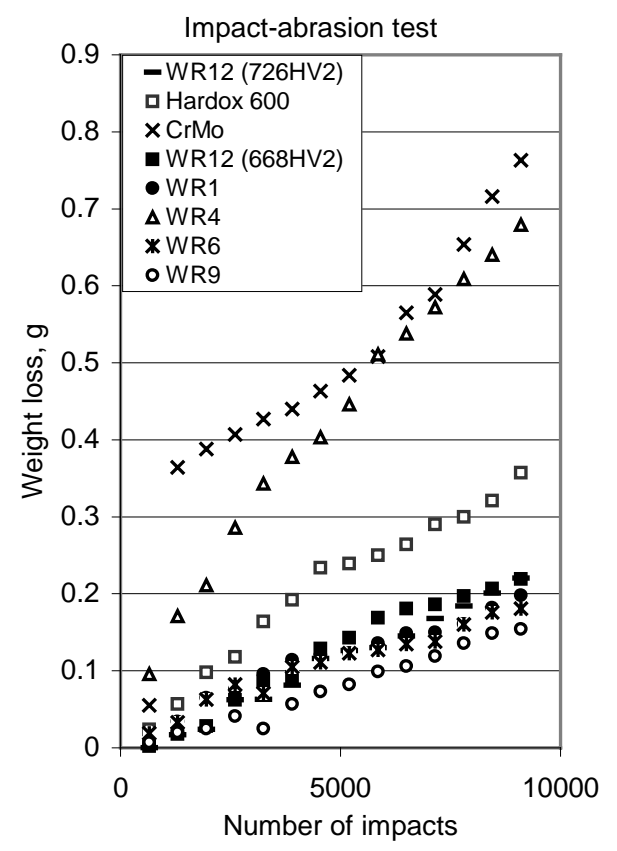

Fig. 5. Impact-abrasion results. 


\subsection{Mechanical properties of tested materials}

Mechanical properties of materials are one of the main factors that influence the wear resistance. This study concentrated on impact toughness and hardness of the materials and their relation to wear. Impact toughness was measured by unnotched Charpy impact test, and hardness with the HV2 method. Results are shown in Table 2.

Microstructural studies of a material can give valuable information on its wear behaviour. Factors like anisotropy, inclusions, defects and secondary phases like carbides and their effect on wear resistance can be analysed. Characterization of the wear surfaces gives information on the wear mechanism that occurs in the material.

Figures 6 and 7 show examples of the microstructures, existing in some of the tested materials. As it can be seen, the HIP material has a very homogeneous microstructure, which leads to equal properties in all directions.

The cross-sections of worn WR4 and WR12 surfaces are shown in Figs. 8 and 9. Several larger cracks and loose particles can be seen in the WR4 sample.

Table 2. Hardness and impact toughness of tested materials

\begin{tabular}{l|c|c|c|c|c|c|c|c}
\hline Material & CrMo & $\begin{array}{c}\text { Hardox } \\
600\end{array}$ & WR1 & WR4 & WR6 & WR9 & WR12(726HV2) & WR12(668HV2) \\
\hline $\begin{array}{l}\text { Hardness } \\
\text { Impact }\end{array}$ & NA & 633 & 810 & 465 & 458 & 751 & 726 & 668 \\
$\begin{array}{c}\text { toughness } \\
\text { NA }\end{array}$ & NA & 35 & 60 & 91.56 & 29.04 & 60 \\
\end{tabular}

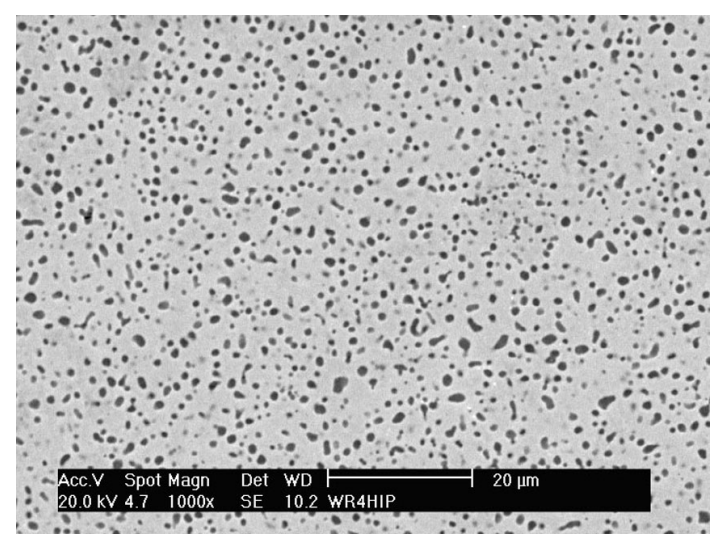

Fig. 6. Microstructure of WR4. 


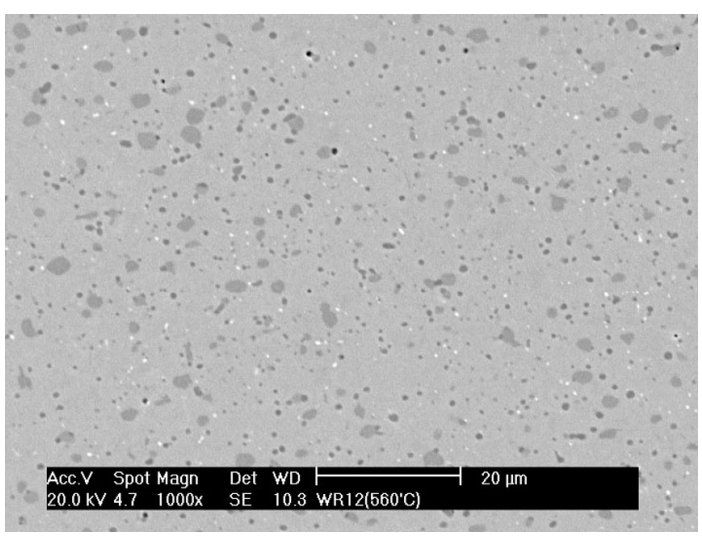

Fig. 7. Microstructure of WR12.

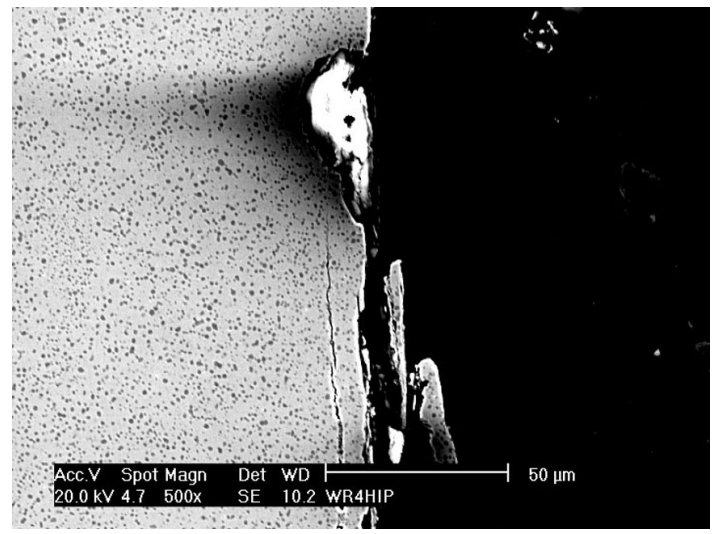

Fig. 8. Cross-section of WR4.

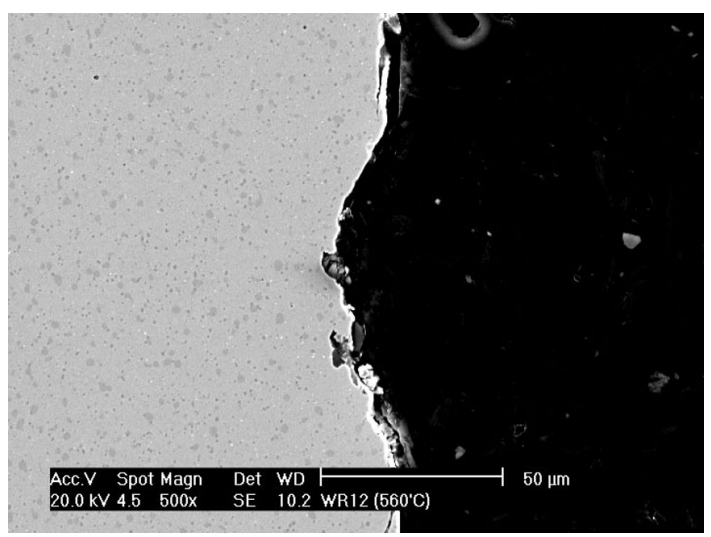

Fig. 9. Cross-section of WR12. 


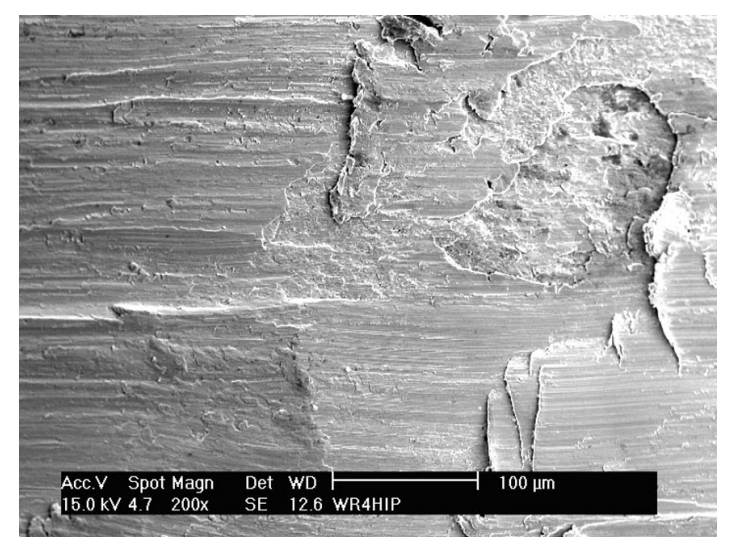

Fig. 10. Worn WR4 surface.

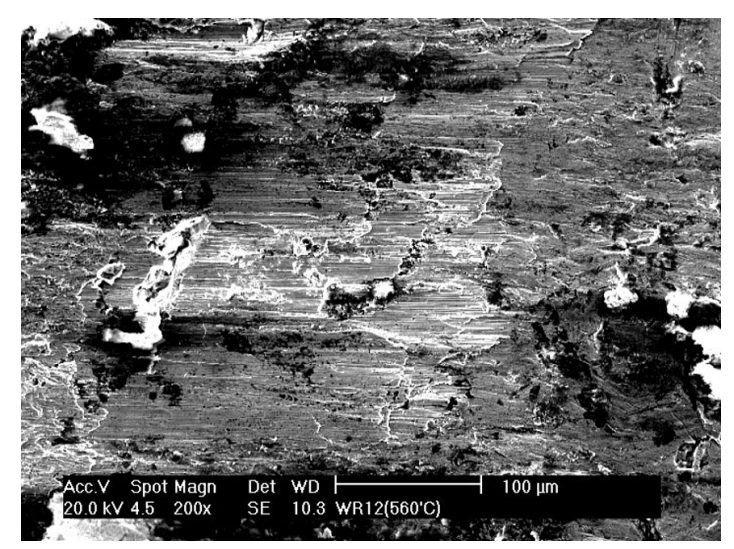

Fig. 11. Worn WR12 surface.

Images of this material were similar to the images taken from the same material after a field test. The cross-section of WR12 seems to be quite different, showing less brittle behaviour due to its higher impact toughness.

The wear surfaces of the same materials are shown in Figs. 10 and 11. These images show that the behaviour of WR4 is much more brittle and fracture is severe. WR12 has deformed as a ductile material, and the most dominant wear mechanisms are flaking, caused by repeated impacts, and cutting and ploughing due to abrasive particles.

\subsection{Comparison of the laboratory and field test results}

The results of the impact wear experiments, conducted in this study, were compared to the results of field tests made with real grinding mills and lifter bars. The field tests were accomplished by Metso. Figures 12a and b, which are taken 


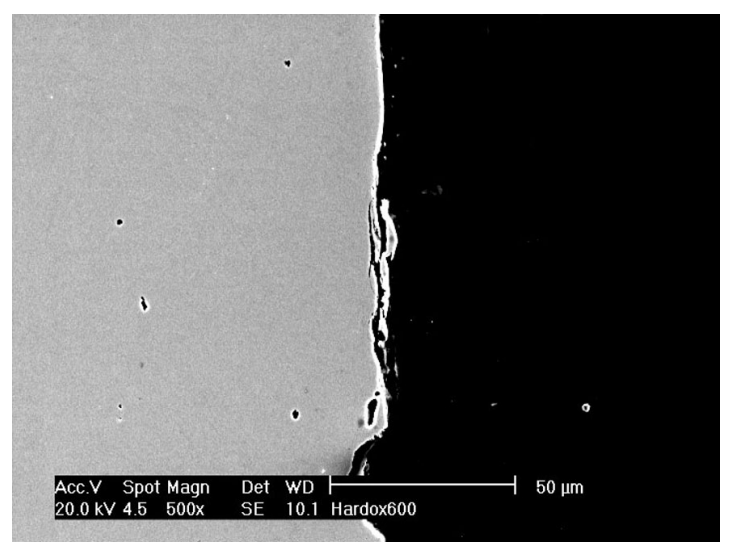

(a)

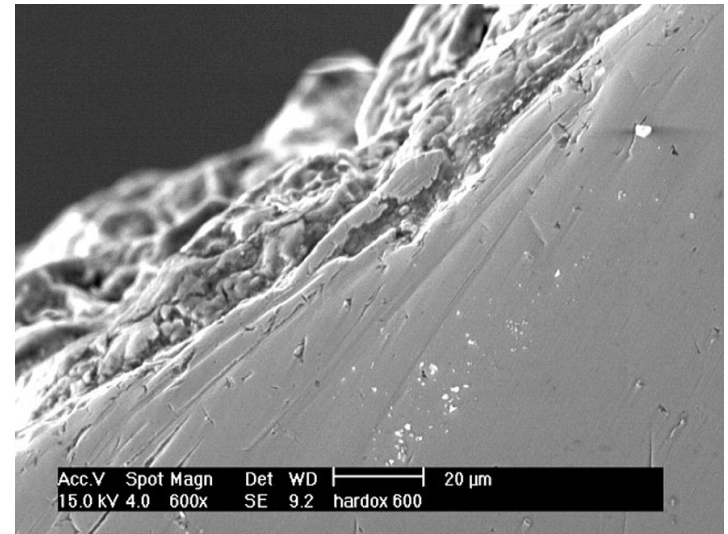

(b)

Fig. 12. Cross-section of the Hardox 600 specimen after the impact wear experiment (a) and after a field test (b).

from the cross-sections of the wear surface, show clear correspondence between the impact test and the field test specimens. Wear and fracture mechanisms, shown in these figures for Hardox 600, seem to be very similar. This is an indication that there is a true correspondence between the active wear mechanisms in the hammer-mill test and in a real grinding mill.

\section{CONCLUSIONS}

1. An existing hammer-mill device was modified to create impact-abrasion and three-body impact wear conditions. Several materials were tested including 
PM materials and commercial reference materials. Properties of the selected material were measured and resistance to different impact wear conditions was characterized.

2. Reference materials gave good starting points for comparisons because of the big differences in their mechanical properties and their different wear behaviour. The best PM materials showed that they have a competitive wear resistance in the tested conditions.

3. The impact wear tests proved that high hardness is not necessarily enough to give good resistance against impacts. Impact toughness plays a key role in avoiding brittle behaviour. The best wear resistance results were obtained when a suitably treated material had high hardness combined with high impact toughness and homogeneous microstructure. These properties were achieved in some PM materials, investigated in this study.

4. Field test results were compared to the laboratory test results. Wear surfaces showed very similar wear behaviour between the hammer-mill specimens and the real worn lifter bar surfaces. According to this, hammer-mill type device can be used in wear tests, simulating the real environment in a grinding mill.

\section{REFERENCES}

1. Kivioja, S., Kivivuori, S. and Salonen, P. Tribologia - Kitka, Kuluminen ja Voitelu. Hakatieto Oy, Helsinki, 1997.

2. Banisi, S. and Hadizadeh, M. 3-D liner wear profile measurement and analysis in industrial SAG mills. Minerals Eng. Forthcoming.

3. Wills, B. A. and Napier-Munn, T. J. Wills' Mineral Processing Technology. Elsevier, Oxford, 2006.

4. Yang, R. Y., Jayasundara, C. T., Yu, A. B. and Curry, D. DEM simulation of the flow of grinding media in IsaMill. Minerals Eng., 2006, 19, 984-994.

5. Teeri, T. Impact Wear Behavior of Novel Materials. M.Sc. Thesis, Tampere University of Technology, Tampere, 2006.

6. Zum Gahr, K.-H. Microstructure and Wear of Materials. Elsevier, Amsterdam, 1987.

7. ASM Handbook, Vol. 18, Friction, Lubrication and Wear Technology. ASM International, USA, 1992

8. Santner, E. and Meier zu Köcker, G. Utility and limitations of tribosimulation for quality control and material preselection. Wear, 1994, 181-183, 350-359.

9. Osara, K. Characterization of Abrasion, Impact-Abrasion and Impact Wear of Selected Materials. Thesis, Tampere University of Technology, Tampere, 2001.

10. Bharat, B. Modern Tribology Handbook. CRC press, Boca Raton, Florida, 2000. 


\title{
Löökkulumine mineraalide peenestamisel
}

\author{
Tuomas Teeri, Veli-Tapani Kuokkala, Pekka Siitonen, \\ Päivi Kivikytö-Reponen ja Jari Liimatainen
}

Mineraalide kaevandamine ja töötlemine nõuab kulumiskindlaid masinaid. Artiklis on vaadeldud masinate detailide löök- ja lõõkabrasiivse kulumise intensiivsust erinevatel töötingimustel. On kasutatud vasarveski-tüüpi seadet, mis tekitab suure energiaga lööke. Katsed on teostatud ka tingimustes, kus abrasiivi on viidud kulutatavate pindade vahele. Mitmete pulbermetallurgiliste materjalide kulumiskindlust on võrreldud etalonmaterjalidega erinevates kulumistingimustes. On vaadeldud materjalide omadusi, mis mõjutavad nende kulumiskindlust. Materjalide mikrostruktuuri ja homogeensust on uuritud peaasjalikult elektronmikroskoobi abil. Katseandmete põhjal on välja töötatud uuritud materjalide klassifikatsioon. 